University of Nebraska - Lincoln

DigitalCommons@University of Nebraska - Lincoln

Publications from USDA-ARS / UNL Faculty

U.S. Department of Agriculture: Agricultural

Research Service, Lincoln, Nebraska

2008

Soil Properties and Macro Cations Status impacted by Long-Term Applied Poultry Litter

\author{
Zhongqi He \\ United States Department of Agriculture-Agricultural Research Service, Zhongqi.He@ars.usda.gov \\ Irenus A. Tazisong \\ Alabama A\&M University \\ Zachary N. Senwo \\ Alabama A\&M University \\ Donglin Zhang \\ University of Maine
}

Follow this and additional works at: https://digitalcommons.unl.edu/usdaarsfacpub

Part of the Agricultural Science Commons

He, Zhongqi; Tazisong, Irenus A.; Senwo, Zachary N.; and Zhang, Donglin, "Soil Properties and Macro Cations Status impacted by Long-Term Applied Poultry Litter" (2008). Publications from USDA-ARS / UNL Faculty. 537.

https://digitalcommons.unl.edu/usdaarsfacpub/537

This Article is brought to you for free and open access by the U.S. Department of Agriculture: Agricultural Research Service, Lincoln, Nebraska at DigitalCommons@University of Nebraska - Lincoln. It has been accepted for inclusion in Publications from USDA-ARS / UNL Faculty by an authorized administrator of DigitalCommons@University of Nebraska - Lincoln. 


\title{
Soil Properties and Macro Cations Status impacted by Long-Term Applied Poultry Litter
}

\author{
Zhongqi He, ${ }^{1}$ Irenus A. Tazisong, ${ }^{2}$ Zachary N. Senwo, ${ }^{2}$ \\ and Donglin Zhang ${ }^{3,4}$ \\ ${ }^{1}$ United States Department of Agriculture, Agricutural Research Service \\ (USDA-ARS), New England Plant, Soil, and Water Laboratory, Orono, \\ Maine, USA \\ ${ }^{2}$ Department of Plant and Soil Science, Alabama A\&M University, \\ Normal, Alabama, USA \\ ${ }^{3}$ Department of Plant, Soil, and Environmental Sciences, University of \\ Maine, Orono, Maine, USA \\ ${ }^{4}$ College of Resource and Environment, Central South Forestry \\ University, Changsha, Hunan, China
}

\begin{abstract}
Most ethnic populations worldwide consume poultry products. Whereas poultry litter (PL) is a traditionally inexpensive and effective fertilizer to improve soil quality and agricultural productivity, overapplication to soils has raised concerns because excess nutrients in runoff could accelerate the eutrophication of fresh bodies of water. A long-term field experiment of land application of PL to soils used for pasture growth has been maintained for nearly two decades in the Sand Mountain region of north Alabama, USA. In this work, several soil parameters impacted by the long-term applied litter were characterized. The findings clearly support previous general observations that long-term applied litter on pasture soils altered soil properties and macrocation levels. Unlike other studies, however, the effects of applied litter at multiple rates and years were examined, thus revealing the dynamic impacts on soil properties. Hay yields increased with the increase of years of PL application, regardless of the applied rate. This observation was consistent with previous observations that the labile phosphorus $(\mathrm{P})$ portion in these soils increases with application years whereas
\end{abstract}

Received 8 December 2006, Accepted 3 June 2007

Trade or manufacturers' names mentioned in the article are for information only and do not constitute endorsement, recommendation, or exclusion by the USDA-ARS.

Address correspondence to Zhongqi He, USDA-ARS, New England Plant, Soil, and Water Laboratory, Orono, ME 04469, USA. E-mail: zhongqi.he@ars.usda.gov 
total P increases with the cumulative applied PL amounts. Poultry litter application did not markedly affect soil electric conductivity, bulk density, or sodium (Na) or potassium $(\mathrm{K})$ levels, especially at the soil surface $(0-20 \mathrm{~cm})$. Soil $\mathrm{pH}$, carbon $(\mathrm{C})$, $\mathrm{C} /$ nitrogen $(\mathrm{N})$ ratio, calcium $(\mathrm{Ca})$, and magnesium $(\mathrm{Mg})$ were profoundly affected at all three soil depths $(0-20,20-40$, and $40-60 \mathrm{~cm})$. Most soil parameters analyzed in this study reached peak values with $10-15$ years of applied litter. This observation suggests that there was a turning point of impact for applied litter around 10 years: prior to that the soil macrocations were altered positively as a result of accumulative functions. Continuous litter application may negatively alter a soil's capacity to retain macrocations, leading to less impact observed in this study. In other words, pasture soils with more than 10 years of applied litter would have higher potential for leaching and runoff. Our observation suggested that best management practices for land application of PL should take into consideration the different effects of PL application history.

Keywords: Calcium, magnesium, pasture soils, poultry litter, soil $\mathrm{pH}$

\section{INTRODUCTION}

Most ethnic populations worldwide consume poultry products. The United States, China, the former Soviet Union states, Brazil, France, and Japan are the dominant production countries (Williams, Barker, and Sims 1999). There is little doubt that the production and consumption of poultry products will continue to increase relative to the world's growing human population and improved life quality (Williams, Barker, and Sims 1999; Zhang et al. 2005). Consequently, environmental impacts of waste byproducts of poultry industries are of increasing importance worldwide. Whereas poultry litter (PL, a mixture of manure and other external materials, such as bedding material) and other animal manures are traditionally inexpensive and used as effective fertilizers to improve soil quality and agricultural productivity, overapplication to soils in areas of extensive animal operations has raised concerns because excess nutrients in runoff could accelerate the eutrophication of fresh bodies of water (Sharpley et al. 1999). Although numerous scientific studies have generated a large body of information on the benefits and environmental effects associated with land-applied animal manure and other wastes (Erich, Fitzgerald, and Porter 2002; McDowell and Sharpley 2004; Toor et al. 2006), long-term studies to document accumulation of elements other than nitrogen $(\mathrm{N})$ and phosphorus $(\mathrm{P})$ in the soil profile due to surface applications of PL are limited (Gascho and Hubbard 2006).

In the relevant literature, Chang and his colleagues (Chang and Janzen 1996; Chang, Sommerfeldt, and Entz 1990, 1991; Whalen and Chang 2001) have investigated the soil chemical and fertility changes in response to repeated annual application of cattle feedlot manure in a long-term (11 years or longer) experiment in nonirrigated and irrigated dark brown Chernozemic soils. Their findings indicated that $\mathrm{N}$, P, salts, and other manure 
nutrients could accumulate in soils with repeated manure applications. Similarly, Ferguson et al. (2005) investigated the long-term (more than a decade) impacts of beef feedlot manure application on nutrient accumulation and movement in a Crete silt loam soil. They found little difference between the effects of manure and composted manure on crop yields, nutrient uptake, or soil nutrient accumulation in the soil. Differences were related primarily to manure application rates rather than source. Eghball, Ginting, and Gilley (2004) reported that applied manure and compost not only improved soil properties for several years after application had ceased but also provided nutrients and liming effects on corn growth. After they investigated environmentally related soil properties in pasture fields, Kingery et al. (1994) found that long-term land-applied broiler litter has altered soil conditions and created potentially adverse environmental impacts in the Sand Mountain region of Alabama, USA. However, there was no evidence that accumulation of nutrients in soils and plants created a forage quality problem due to longterm applied litter (Kingery et al. 1993).

A long-term field experiment of land-applied litter to pasture soils has been maintained for two decades at the Sand Mountain region of north Alabama, USA (He et al. 2005; Tazisong, Senws, and Taylor 2005). The objectives of this study were to evaluate the impact of PL application history $(0,5,10,15$, and 20 years $)$ on (1) the $\mathrm{pH}$, electric conductivity (EC), and bulk density (BD) of these soils and (2) accumulation and distribution of macrocations [sodium $(\mathrm{Na})$, potassium $(\mathrm{K})$, calcium $(\mathrm{Ca})$, and magnesium $(\mathrm{Mg})]$ through soil profiles $(0-60 \mathrm{~cm})$. We determined these soil parameters because most nutrient research data had focused on $\mathrm{N}$ and $\mathrm{P}$ without considerations of other nutrients impacted by PL application (Gascho and Hubbard 2006). Information obtained from this study is helpful in comprehensively assessing potential environmental risks associated with long-term PL disposal on land.

\section{MATERIALS AND METHODS}

\section{Soils}

Soils were collected from slope positions ( 3 to $8 \%$ slope) of the Hartselle (fine sandy loam, siliceous, thermic, Typic Hapludults) soil series in the Sand Mountain region of north Alabama, USA. Samples were collected randomly at three locations in each field at depth increments of 0-20, 20-40, and $40-60 \mathrm{~cm}$. Soil samples in five fields had received poultry litter continuously for past 0 (control), 5, 10, 15, and 20 years at rates of 0 (control), 2.27, 2.27, 3.63 , and $1.36 \mathrm{Mg} \mathrm{ha}^{-1} \mathrm{yr}^{-1}$, respectively (Figure 1). These fields were hayed and fertilized with litter only and were being managed for pasture without supplemental inorganic N, P, or K fertilizers. The chemical composition of PL is listed in Table 1 . The soil samples were air dried, ground to pass a 2-mm 


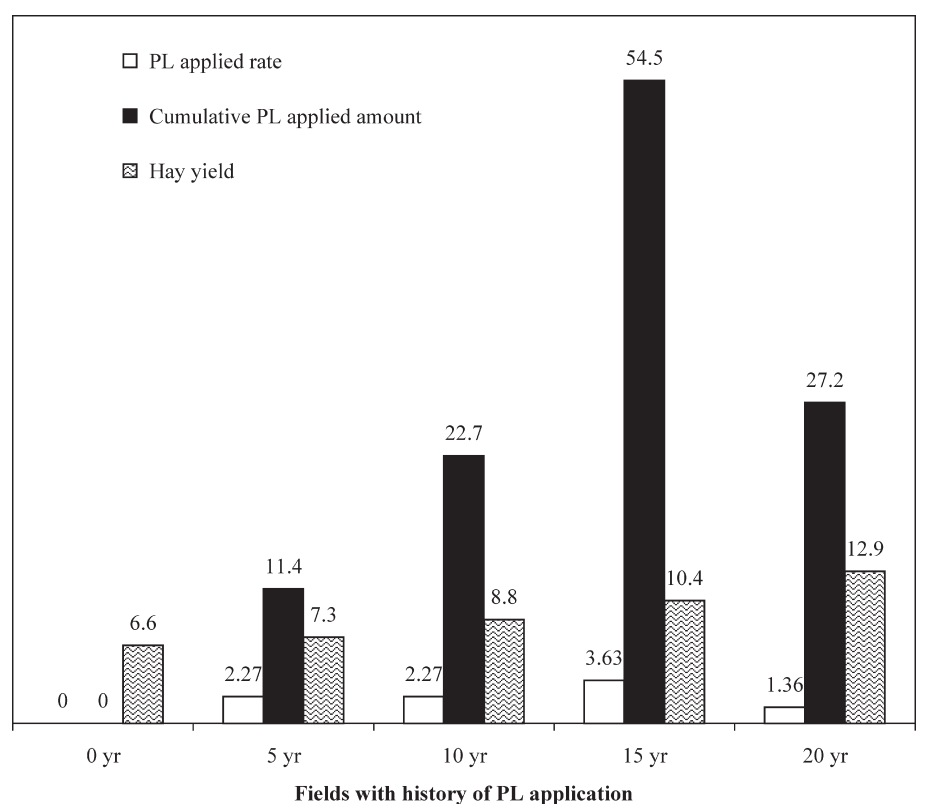

Figure 1. Annual rate $\left(\mathrm{Mg} \mathrm{ha}^{-1} \mathrm{yr}^{-1}\right)$ and cumulative amounts $\left(\mathrm{Mg} \mathrm{ha}^{-1}\right)$ of poultry litter applied, and hay yields $\left(\mathrm{Mg} \mathrm{ha}^{-1}\right)$ of five fields.

stainless steel sieve, and stored in plastic bags at room temperature. Subsamples were also ground to pass a 100-mesh sieve for total metal determinations.

\section{Physical and Chemical Analyses}

Soil $\mathrm{pH}$ was measured in water at a soil-to-solution ratio of 1:2. The filtrated extracts of the soil-water mixtures were used for electrical conductivity (EC) measurements. The EC values were temperature-compensated to $25^{\circ} \mathrm{C}$. Soil bulk density (BD) was calculated by dividing the mass of soil, corrected for moisture content, by the volume of soil collected (Blake and Hartge 1986). Soils were digested and filtered using vacuum suction for total $\mathrm{Ca}, \mathrm{Mg}, \mathrm{K}$, and $\mathrm{Na}$ determination (Sommers and Nelson 1972). Contents of these four elements in the digests were determined with inductively coupled plasmaatomic emission spectroscopy (ICP-AES, Perkin-Elmer Plasma 400 emission spectrophotometer, Norwalk, CT). For extractable $\mathrm{Ca}, \mathrm{Mg}, \mathrm{K}$, and $\mathrm{Na}$ contents, soils $(2.5 \mathrm{~g})$ were extracted with Mehlich III [0.2 M acetic acid $\left(\mathrm{CH}_{3} \mathrm{COOH}\right)+0.25 \mathrm{M}$ ammonium nitrate $\left(\mathrm{NH}_{4} \mathrm{NO}_{3}\right)+0.015 \mathrm{M}$ ammonium fluoride $\left(\mathrm{NH}_{4} \mathrm{~F}\right)+0.13 \mathrm{M}$ nitric acid $\left(\mathrm{HNO}_{3}\right)+0.001 \mathrm{M}$ ethylenediaminetetraacetic acid (EDTA)] extractant $(25 \mathrm{~mL})$ at $\mathrm{pH} 2.5$ for 5 min (Mehlich 1984) prior to ICP-AES analysis. 
Table 1. Selected parameters of poultry litter based on 23 samples $^{a}$

\begin{tabular}{|c|c|c|c|c|c|c|c|c|c|}
\hline Sample & $\mathrm{pH}$ & $\begin{array}{l}\mathrm{C}\left(\mathrm{g} \mathrm{kg}^{-1}\right. \\
\text { dry matter })\end{array}$ & $\begin{array}{l}\mathrm{N}\left(\mathrm{g} \mathrm{kg}^{-1}\right. \\
\text { dry matter) }\end{array}$ & $\begin{array}{l}\mathrm{S}\left(\mathrm{g} \mathrm{kg}^{-1}\right. \\
\text { dry matter) }\end{array}$ & $\begin{array}{l}\mathrm{P}\left(\mathrm{g} \mathrm{kg}^{-1}\right. \\
\text { dry matter) }\end{array}$ & $\begin{array}{l}\mathrm{Fe}\left(\mathrm{g} \mathrm{kg}^{-1}\right. \\
\text { dry matter) }\end{array}$ & $\begin{array}{l}\mathrm{Al}\left(\mathrm{g} \mathrm{kg}^{-1}\right. \\
\text { dry matter) }\end{array}$ & $\begin{array}{l}\mathrm{Ca}\left(\mathrm{g} \mathrm{kg}^{-1}\right. \\
\text { dry matter) }\end{array}$ & $\begin{array}{l}\mathrm{Mg}\left(\mathrm{g} \mathrm{kg}^{-1}\right. \\
\text { dry matter) }\end{array}$ \\
\hline Range & $7.8-8.9$ & $256-365$ & $36-73$ & $5-24$ & $12-30$ & $0.7-4.8$ & $0.6-6.2$ & $17-45$ & $4.8-10.1$ \\
\hline Average & 8.2 & 311 & 50 & 10 & 22 & 1.9 & 2.0 & 28 & 7.6 \\
\hline $\begin{array}{l}\text { Standard } \\
\quad \text { deviation }\end{array}$ & 0.3 & 33 & 10 & 5 & 4 & 1.2 & 1.7 & 7 & 1.3 \\
\hline
\end{tabular}

${ }^{a}$ Data are derived from He et al. (2006). 


\section{Statistical Analysis}

All data are presented as the average of three replicates. The single-factor ANOVA (analysis of variance) statistical tool was used to evaluate the differences of soil properties impacted by different treatments.

\section{RESULTS AND DISCUSSION}

\section{Hay Yields and Soil C Contents}

The five fields had received PL continuously at different application rates. Thus, the cumulative amounts applied did not increase with the increasing years of application (Figure 1). The highest cumulative amount was $54.5 \mathrm{Mg} \mathrm{ha}^{-1}$ in the plot with 15 years of application. The hay yields increased in all four fields receiving PL application (Figure 1). However, the increase was irrelevant to the annual rate or the cumulative amount of PL but instead related to the years of application. This observation indicated that not all nutrients in PL applied to soils immediately became available for plant uptake, as residual effects of manure or composition application on crop production and soil properties can last for several years (Eghball, Ginting, and Gilley 2004). Previously, He et al. (2005) found that PL application impacted soil P levels in two patterns. The levels of labile inorganic $\mathrm{P}$ were more related to the years of application, whereas the levels of stable P were related to the cumulative amount of PL applied. The increase in yield we observed in this study was consistent with the levels of labile P impacted by PL application.

Poultry litter application also significantly increased soil $\mathrm{C}$ content to a depth of $40 \mathrm{~cm}$ (Figure 2). The $\mathrm{C}$ content reached the maximum in the field with 10-15 years of PL application, approximately to the order of cumulative amount of PL applied. The increase indicated a great potential benefit for increasing soil C by PL application. The accumulation of $\mathrm{C}$ contents in littered soil was consistent with some previous results (Kingery et al. 1994; Gascho and Hubbard 2006) but in contrast to others (Cooper et al. 1984; Jackson, Leonard, and Wilkinson 1975). The control soil had C/N ratios of $12.1,9.1$, and 7.0 in depths of $0-20,20-40$, and $40-60 \mathrm{~cm}$, respectively (Figure 2). The application of PL resulted in further lower $\mathrm{C} / \mathrm{N}$ ratios in the upper surface soils (Figure 2). The $\mathrm{C} / \mathrm{N}$ ratios of less then 20 suggested faster mineralization of litter materials in releasing nutrient elements (Tasizong, Senwo, and Taylor 2005), specifically production of inorganic N via net mineralization of organic material (Kingery et al. 1994).

\section{Soil Properties}

In the plot without applied litter, soil $\mathrm{pH}$ was 5.1, 4.9, and 4.8 at depths of $0-20,20-40$, and $40-60 \mathrm{~cm}$, respectively (Figure 3a). Poultry litter 

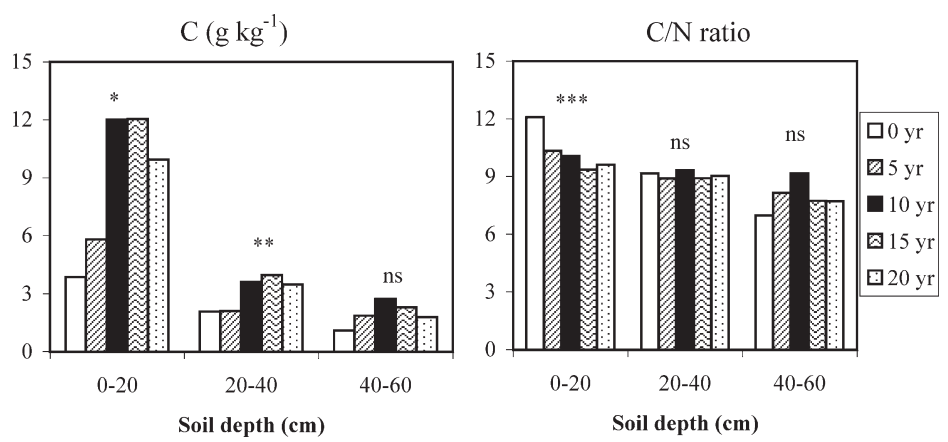

Figure 2. Changes of $\mathrm{C}$ and $\mathrm{C} / \mathrm{N}$ ratios impacted by poultry litter application. *, **, and ${ }^{* *}$ denote significance at $\alpha=0.05,0.01$ and 0.001 , respectively; ns, no significance at $\alpha=0.05$.

application led to $\mathrm{pH}$ increase in all plots. At the 0 to $20-\mathrm{cm}$ depth, the increase reached the maximum ( $\mathrm{pH} \mathrm{6.4)} \mathrm{with} 10$ years of applied litter. At the 20 to 40$\mathrm{cm}$ depth, however, the maximum $(\mathrm{pH}$ 6.3) reached at the plot was with 15 years of applied litter, corresponded to the maximal cumulative amount of applied litter. At the 40 to $60-\mathrm{cm}$ depth, the maximum ( $\mathrm{pH} \mathrm{6.3)} \mathrm{was}$ observed at the plot with the longest applied litter history (20 years). The increase in $\mathrm{pH}$ seems due to the higher $\mathrm{pH}$ values of PL themselves (Table 1) and within the optimum range $(\mathrm{pH} 6.0$ to 6.5) for agronomic crops (Gascho and Hubbard 2006). The results confirmed previous observations that long-term application of litter increased $\mathrm{pH}$ (Kingery et al. 1994). In contrast, a short-term (2-year) application could make little or no change in soil pH (Evers 1998; Jackson, Leanard, and Wilkinson 1975).

Electrical conductivity (EC) was higher in litter-applied soils through most soil depths (Figure 3b), which was consistent with a previous observation (Kingery et al. 1994). The trends in EC change were roughly in the order of annual application rate of litter, suggesting EC was not affected in a cumulative manner by repeated applications. The accumulation of soluble salts from PL application would be minimal because these added soluble salt components could leach out continuously throughout the soil profiles (Chang, Sommer feldt, and Entz 1990; Weil, Kroontje, and Jones 1979). This observation suggests that any potential EC increase to detrimental value of $0.4 \mathrm{ds} \mathrm{m}^{-1}$ (Kingery et al. 1994; Shortall and Liebhardt 1975) should be avoided by controlling the rate rather than the history of application.

There were only little impacts of application on the soil bulk density (Figure 3c). In contrast to the cases of $\mathrm{pH}$ and $\mathrm{EC}$, the impacts at all three soil depths were similar; that is, the least $\mathrm{BD}$ values were observed with 10 -year plots although the significant difference was only shown at the 40 to $60-\mathrm{cm}$ depth. The relatively uniform pattern of BD over the three soil depths would be considered as reasonable for pasture soils with no disturbing 

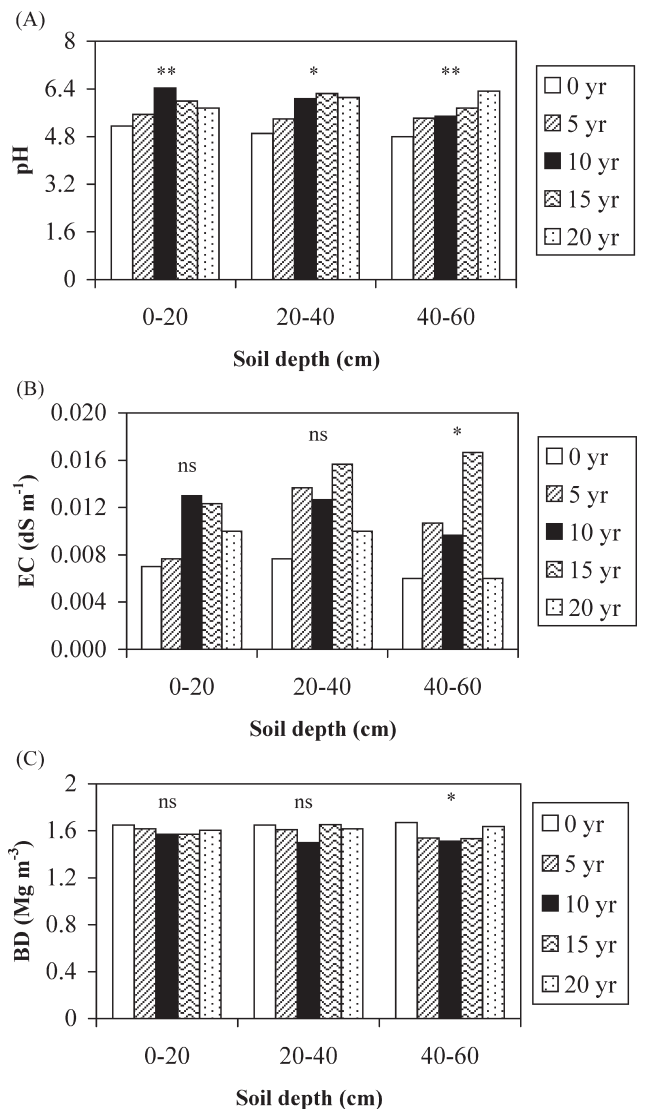

Figure 3. Soil properties impacted by poultry litter application: (A) $\mathrm{pH}$, (B) electric conductivity, and (C) bulk density. ${ }^{*}$ and ${ }^{* *}$ denote significance at $\alpha=0.05$ and 0.01 , respectively; ns, no significance at $\alpha=0.05$.

tillage practice. Soil BD is an indicator of soil compaction, aeration, and developmental ease of roots (Celik, Ortas, and Kilic 2004). Our observation implies that this soil property should not be a major concern when applying litter to agricultural lands.

\section{Na and K Contents}

Total $\mathrm{Na}$ content in the pasture soil without applied litter was around $300 \mathrm{mg} \mathrm{kg}^{-1}$ at the 0 - to 20 - and 20 - to $40-\mathrm{cm}$ depths, and $200 \mathrm{mg} \mathrm{kg}^{-1}$ at the 40 to $60-\mathrm{cm}$ depth (Figure $4 \mathrm{a}$ ). Poultry litter application did not significantly affect the total $\mathrm{Na}$ levels. Mehlich 3 -extractable Na was 10 to $8 \mathrm{mg}$ $\mathrm{kg}^{-1}$ at the plot depths without applied litter. The impact of applied litter 
on soluble $\mathrm{Na}$ was more apparent and significant than on total $\mathrm{Na}$, especially at the 20- to 40 - and 40 to 60 -cm depths. The greatest increase at the two depths occurred at the plot with 10 years of applied litter, which is inconsistent with the order of annual rates or cumulative amounts. This result could be due to the combined interactions of leaching and accumulation. The former tended to reduce the soluble $\mathrm{Na}$ content over time, and the latter tended to increase the soluble Na content over time. Previously, Chang, Sommerfeldt, and Entz (1990, 1991) observed that soluble Na content increased with longterm applied cattle feedlot manure. They found that soluble Na content was highest at the 30 - to $60-\mathrm{cm}$ depth under no irrigation and at $60-90 \mathrm{~cm}$ under irrigation conditions. Evers (1998) found that although there was no significant difference at the 0 - to $15-\mathrm{cm}$ depth, it was significant at the 0 - to $30-\mathrm{cm}$ depth, in acetate/EDTA-extractable $\mathrm{Na}$ in a pasture soil with 2 years of applied PL. Franzluebbers, Wilkinson, and Stueddemann (2004) demonstrated that accumulation of total soil $\mathrm{Na}$ in the surface $6 \mathrm{~cm}$ of soil growing Coastal Bermudagrass was only about $15 \%$ of that applied litter at the end of 5 years, and leaching of $\mathrm{Na}$ below the soil surface likely occurred.
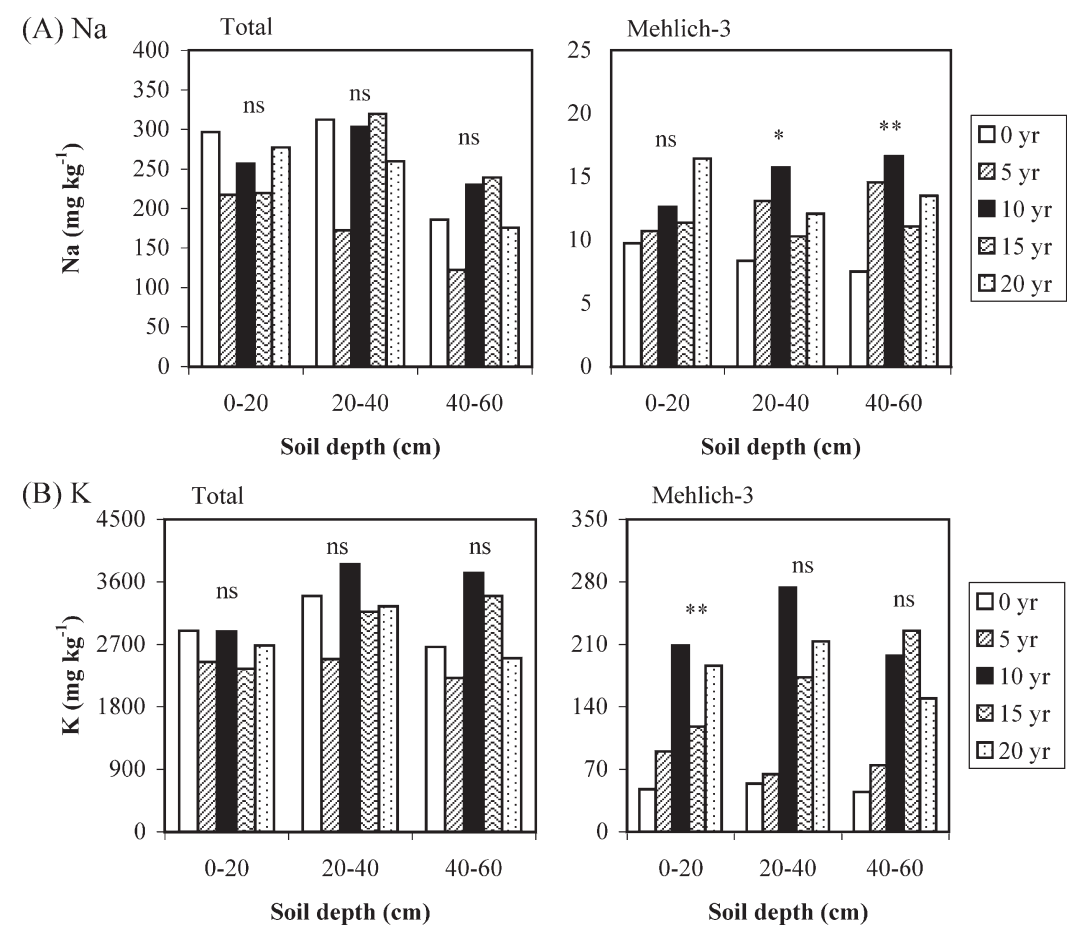

Figure 4. Changes of $\mathrm{Na}$ and $\mathrm{K}$ impacted by poultry litter application: (A) $\mathrm{Na}$ and (B) $\mathrm{K} .{ }^{*}$ and $^{* *}$ denote significance at $\alpha=0.05$ and 0.01 , respectively; ns, no significance at $\alpha=0.05$. 
The total K content was about 10-fold higher than total Na. However, the total K-distribution patterns were similar to those of total $\mathrm{Na}$ at all soil depths (Figure 4b), indicating the similarities in chemical properties of these two alkaline metal ions. However, the pattern of Mehlich 3-extractable K was not similar to its $\mathrm{Na}$ counterpart. Poultry litter application had a greater impact on Mehlich 3-extractable K than on Mehlich 3-extractable Na, as compared to the relative increase of their contents in plots with no PL applied. The increase was from 2-fold at the plot with 5 years of applied litter to 4-fold at the plots with 10- and 20-year applications. These data were consistent with previous reports whereby Evers (1998) reported that 2 years of applied PL $\left(9 \mathrm{Mg} \mathrm{ha}^{-1} \mathrm{y}^{-1}\right)$ raised ammonia acetate/EDTA-extractable $\mathrm{K}$ by $43 \%$ at the 0 - to $15-\mathrm{cm}$ depth of Bermudagrasss pasture fields. Kingery et al. (1994) found that extractable soil $\mathrm{K}$ at $0-$ to $15-\mathrm{cm}$ depth of pasture soil increased by nearly 3-fold at 21 years of applied PL with $11 \pm 5 \mathrm{Mg} \mathrm{ha}^{-1} \mathrm{y}^{-1}$. The significant change in extractable $\mathrm{K}$ occurred at the upper surface soil, which suggests the value of PL as a source of K nutrition.

\section{Ca and Mg Contents}

Total Ca content of the plot without applied litter was lower $\left(<200 \mathrm{mg} \mathrm{kg}^{-1}\right)$ (Figure 5a). Poultry litter application increased the Ca content by 2- to 7 - fold at the 0 - to $20-\mathrm{cm}$ depth, parallel to the cumulative amounts of applied litter. The total $\mathrm{Ca}$ content at the depths of $20-40$ and $40-60 \mathrm{~cm}$ increased in a similar manner with smaller amplitudes. Among the $\mathrm{Ca}$ in the unlittered soil, about one-half was Mehlich 3-extractable Ca (i.e., 206, 166, and $89 \mathrm{mg}$ total $\mathrm{Ca} \mathrm{kg}^{-1}$ vs. 106, 69, and $39 \mathrm{mg}$ total $\mathrm{Ca} \mathrm{kg}^{-1}$ in $0-20,20-40$, and $40-60 \mathrm{~cm}$, respectively). Poultry litter application increased Mehlich 3 -extractable $\mathrm{Ca}$ at the 0 - to 20 -cm depth by 2- to 7-fold, similar to those of total $\mathrm{Ca}$. However, a higher percentage of Mehlich 3-extractable $\mathrm{Ca}$ leached to deeper soil profiles. The increase of Mehlich 3-extractable $\mathrm{Ca}$ was roughly equal to the increase of total $\mathrm{Ca}$ in the depths of 20-40 and $40-60 \mathrm{~cm}$. For instance, the increase in the depth of $20-40 \mathrm{~cm}$ in the soil with 15 years of PL application was 490 total Ca and 477 Mehlich 3extractable $\mathrm{Ca} \mathrm{kg}^{-1}$ soil. This observation indicated that most of the $\mathrm{Ca}$ leached down was Mehlich 3-extractable Ca. Unlike other metals, the impacts of applied litter on both total and Mehlich-3-extracable $\mathrm{Ca}$ at all soil depths were significant. This is probably due to $\mathrm{Ca}$ being least soluble and more inclined to mobilize in soils as sulfates, phosphates, and carbonates (Chang, Sommerfedt, and Entz 1991). The increase in Ca content, especially at the upper surface soil, due to applied litter has been previously observed (Jackson, Leonard, and Wilkinson 1975; Kingery et al. 1994; Gascho and Hubbard 2006).

The baseline contents of total $\mathrm{Mg}$ were much higher than that of total $\mathrm{Ca}$ at the plot without applied PL (Figure 5b). On the other side, the contents of 

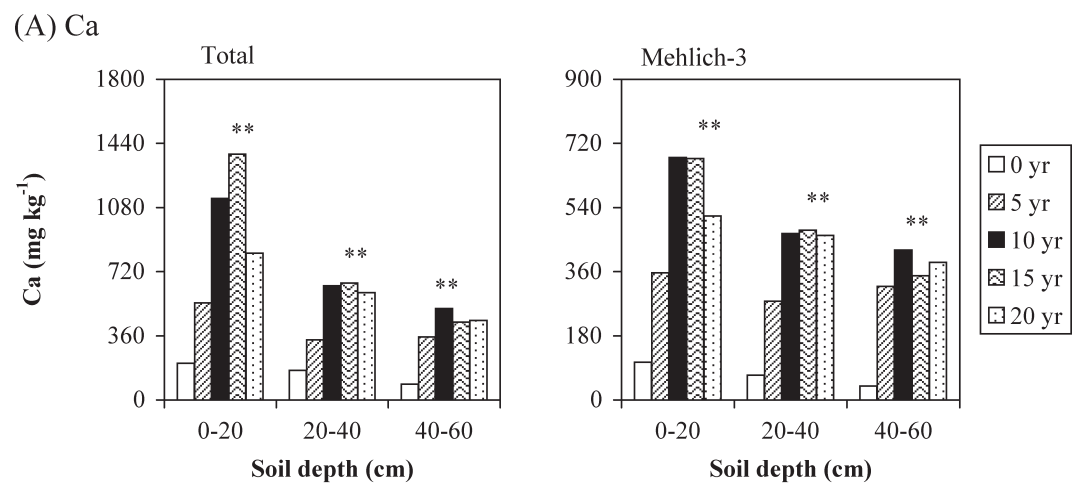

(B) $\mathrm{Mg}$
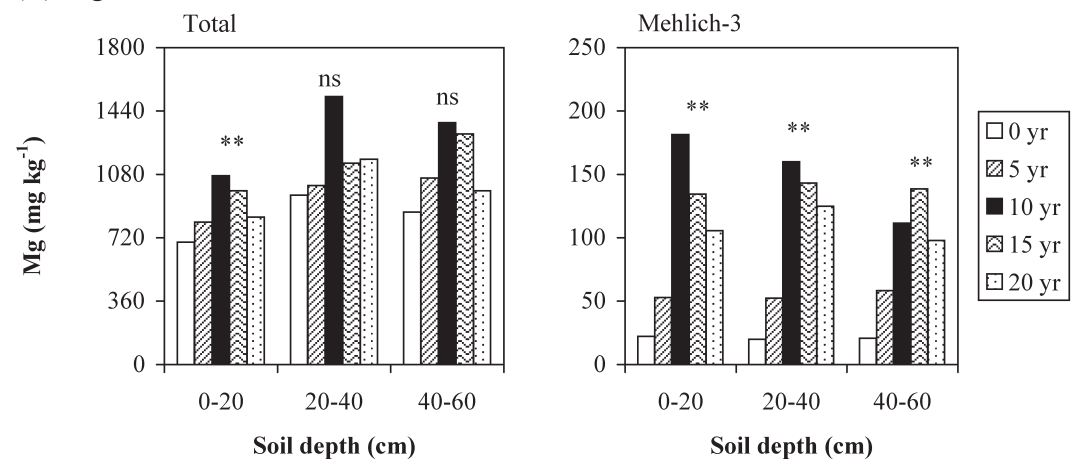

Figure 5. Changes of $\mathrm{Ca}$ and $\mathrm{Mg}$ impacted by poultry litter application: (A) $\mathrm{Ca}$ and (B) $\mathrm{Mg} .{ }^{*}$ and ${ }^{* *}$ denote significance at $\alpha=0.05$ and 0.01 , respectively; ns, no significance at $\alpha=0.05$.

Mehlich 3-extractable $\mathrm{Mg}$ (around $20 \mathrm{mg} \mathrm{kg}^{-1}$ ) were lower than those of Mehlich 3-extratable $\mathrm{Ca}$ at all depths (Figure 4b). The increase in total $\mathrm{Mg}$ by applied litter was smaller than that of total $\mathrm{Ca}$, apparently due to the low $\mathrm{Mg}$ and high $\mathrm{Ca}$ contents in PL (He et al. 2006). The significant and dramatic increase of Mehlich 3-extractable Mg, however, was observed at all soil depths (2-9-fold). The similar contents and patterns of Mehlich 3-extracted Mg at all depths suggested that Mehlich 3-extracted Mg significantly leached down and was distributed across the soil depths as previously observed (Kingery et al. 1994).

\section{Relationships among Soil Parameters impacted by Applied PL}

The findings in this study support the general conclusion that PL application either prevents a decline or contributes to an increase in macrocations concentrations in pasture soils (Evers 1998; Franzluebbers, Wilkinson, and 
Stueddemann 2004; Jackson, Leonard, and Wilkinson 1975; Kingery et al. 1994). However, most of the soil parameters analyzed in this study did not increase correspondingly to the rates, cumulative amounts, and years of applied litter, but rather were at peak values with 10 years of applied litter. This observation is in contrast to our observations of soil $\mathrm{P}$ status of applied litter on these plots (He et al. 2005). Using a sequential fractionation coupled with enzymatic hydrolysis, He, Griffin, and Honey cutt (2004a, $2004 \mathrm{~b})$ suggest that the long-term applied litter impacted surface (0- to $20-\mathrm{cm}$ ) soil P levels in two patterns. The levels of labile inorganic P were more related to the number of years receiving PL. The levels of stable inorganic $\mathrm{P}$ were related to the cumulative amount of applied litter, which implies that the stable P in PL is accumulated in soils and gradually transformed to labile $\mathrm{P}$ for plant uptake. The difference probably is because the macrocations investigated in this study was more soluble; thus, leaching and runoff were more important factors than mineral fixation after longterm applied litter (10 years), leading to an increase less relevant to the cumulative amounts or years of applied litter.

It is proposed that the high input of $\mathrm{K}$ to soil from applied litter is largely responsible for the migration and translocation of $\mathrm{Ca}$ and $\mathrm{Mg}$ (Jackson, Leoard, and Wilkinson 1975). In a 2- year experiment, the authors (Jackson, Leonard, and Wilkinson 1975) demonstrated that heavy rates of applied PL resulted in large quantities of $\mathrm{K}$ being made available in very acid soil profiles, whereas exchangeable $\mathrm{Ca}$ and $\mathrm{Mg}$ were depleted. Our results on the long-term litter application did not support this observation, whereas the reverse relationships among the extractable $\mathrm{K}, \mathrm{Ca}$, and $\mathrm{Mg}$ concentrations were observed also in a 5-year experiment (Franzluebbers, Wilkinson, and Stueddemann 2004). In our study, neither total nor Mehlich 3-extractable $\mathrm{K}$ was negatively relevant to its $\mathrm{Ca}$ and $\mathrm{Mg}$ (Figures 3 and 4) counterparts, which was consistent with the observed values of 21 years of applied litter on a pasture soil (Kingery et al. 1994). The different observations were probable partly due to the different histories of applied litter and different extractants used.

Hue (1992) observed that PL was as effective as calcium hydroxide $\left[\mathrm{Ca}(\mathrm{OH})_{2}\right]$ in raising the $\mathrm{pH}$ of acid Hawaiian soils. In our study, the elevated levels of $\mathrm{Ca}$ and $\mathrm{Mg}$ impacted by PL application were in the same order of $\mathrm{pH}$ increase at depths of $0-20 \mathrm{~cm}$ and $20-40 \mathrm{~cm}$ (Figures 3 and 5). Linear regression analysis further confirmed the correlations between $\mathrm{pH}$ and $\mathrm{Ca}$ as well as $\mathrm{Mg}$ (Table 2). Except in the case of total $\mathrm{Mg}$ at $20-40 \mathrm{~cm}$, which was not significantly different, all other linear regressions show quite high $\mathrm{R}^{2}$ values. This observation demonstrates that the $\mathrm{pH}$ change impacted by applied litter was due to $\mathrm{Ca}$ and $\mathrm{Mg}$ salts in PL. In the meantime, this relationship could be used as a rapid method to estimate the change in $\mathrm{Ca}$ and $\mathrm{Mg}$ by simply measuring the soil $\mathrm{pH}$ change, provided the correlations in Table 2 could be confirmed by more field data. 
Table 2. Relationships between soil $\mathrm{pH}$ and contents of $\mathrm{Ca}$ and $\mathrm{Mg}$

\begin{tabular}{clllll}
\hline & \multicolumn{2}{c}{$\mathrm{pH}$} & & \multicolumn{2}{c}{$\Delta \mathrm{pH}$} \\
\cline { 2 - 3 } \cline { 6 - 6 } & Linear regression & $\mathrm{R}^{2}$ & & Linear regression $^{a}$ & $\mathrm{R}^{2}$ \\
\hline 0-20 cm deep & & & & \\
Total & $\mathrm{Ca}=836 \mathrm{pH}-4011$ & 0.75 & & $\Delta \mathrm{Ca}=929 \Delta \mathrm{pH}$ & 0.74 \\
& $\mathrm{Mg}=306 \mathrm{pH}-890$ & 0.97 & & $\Delta \mathrm{Mg}=298 \Delta \mathrm{pH}$ & 0.96 \\
Mehlich-3 & $\mathrm{Ca}=472 \mathrm{pH}-2259$ & 0.88 & & $\Delta \mathrm{Ca}=542 \Delta \mathrm{pH}$ & 0.85 \\
& $\mathrm{Mg}=130 \mathrm{pH}-651$ & 0.97 & & $\Delta \mathrm{Mg}=125 \Delta \mathrm{pH}$ & 0.97 \\
20-40 cm deep & & & & & \\
Total & $\mathrm{Ca}=377 \mathrm{pH}-1686$ & 0.99 & & $\Delta \mathrm{Ca}=374 \Delta \mathrm{pH}$ & 0.99 \\
& $\mathrm{Mg}=247 \mathrm{pH}-259$ & $0.42^{b}$ & & $\Delta \mathrm{Mg}=240 \Delta \mathrm{pH}$ & $0.42^{b}$ \\
Mehlich-3 & $\mathrm{Ca}=304 \mathrm{pH}-1401$ & 0.98 & & $\Delta \mathrm{Ca}=327 \Delta \mathrm{pH}$ & 0.92 \\
& $\mathrm{Mg}=101 \mathrm{pH}-482$ & 0.92 & & $\Delta \mathrm{Mg}=97 \Delta \mathrm{pH}$ & 0.92 \\
\hline
\end{tabular}

Note: Contents of $\mathrm{Ca}$ and $\mathrm{Mg}$ in $\mathrm{mg} \mathrm{kg}^{-1}, \Delta \mathrm{pH}, \Delta \mathrm{Ca}$, and $\Delta \mathrm{Mg}$ represented the increased value/contents due to PL application.

${ }^{a}$ Intercept was set at zero.

${ }^{b}$ Change of $\mathrm{Mg}$ content was not significant at $\alpha=0.5$.

\section{CONCLUSIONS}

Our findings in this study clearly support previous general observation that long-term applied PL on pasture soils altered soil properties and macrocations levels. However, unlike previous studies, which examined the alteration of soil parameters at the end of applied litter, we examined the effects of applied litter at multiple rates and years, thus revealing their dynamic impacts. Poultry litter application increased hay yields with the year of PL application, regardless the applied rates. However, PL application did not markedly affect soil $\mathrm{EC}, \mathrm{BD}, \mathrm{Na}$, or $\mathrm{K}$, especially at the soil surface $(0-20 \mathrm{~cm})$. Soil $\mathrm{pH}, \mathrm{C}, \mathrm{C} / \mathrm{N}$ ratio, $\mathrm{Ca}$, and $\mathrm{Mg}$ were profoundly affected by applied litter at the surface $(0-20 \mathrm{~cm})$ or all the soil depths $(0-20,20-40$, and $40-60 \mathrm{~cm}$ ) studied. However, changes of these parameters were not always in the order of the increasing annual rates, cumulative amounts, or years of applied litter, indicating that multiple immobilization (such as mineral fixation) and mobilization (such as runoff, leaching, and plant uptake) processes with different dynamic characteristics occurred in the littered soils. Our results indicate a more comprehensive investigation is required to quantitatively predict the impacts of long-term applied litter on soil properties and macrocations. However, we observed close relationships between elevated soil $\mathrm{pH}$ and increased amounts of $\mathrm{Ca}$ and $\mathrm{Mg}$ at the 0 - to 20- and 20- to 40-cm depths. Our observation suggested that best management practices for land application of PL should take the different history of PL application into consideration. 


\section{REFERENCES}

Blake, G.R. and Hartge, K.H. (1986) Bulk density. In Methods of Soil Analysis: Part 1: Physical and Mineralogical Methods; Klute, A. (ed.); ASA: Madison, Wisc.: $363-375$.

Celik, I., Ortas, I., and Kilic, S. (2004) Effects of compost, mycorrhiza, manure and fertilizer on some physical properties of a chromoxert Soil. Soil and Tillage Research, 78: 59-67.

Chang, C. and Janzen, H.H. (1996) Long-term fate of nitrogen from annual feedlot manure applications. Journal of Environmental Quality, 25: 785-790.

Chang, C., Sommerfeldt, T.G., and Entz, T. (1990) Rates of soil chemical changes with eleven annual applications of cattle feedlot manure. Canadian Journal of Soil Science, 70: 673-681.

Chang, C., Sommerfeldt, T.G., and Entz, T. (1991) Soil chemistry after eleven annual applications of cattle feedlot manure. Journal of Environmental Quality, 20: 475-480.

Cooper, J.R., Reneau, R.B., Jr., Kroontje, W., and Jones, G.D. (1984) Distribution of nitrogenous compounds in a rhodic paleudult following heavy manure application. Journal of Environmental Quality, 13: 189-193.

Eghball, B., Ginting, D., and Gilley, J.E. (2004) Residual effects of manure and compost application on corn production and soil properties. Agronomy Journal, 96: $442-447$.

Erich, M.S., Fitzgerald, C.B., and Porter, G.A. (2002) The effect of organic amendments on phosphorus chemistry in a potato cropping systems. Agriculture, Ecosystems and Environment, 88: 79-88.

Evers, G.W. (1998) Comparison of boiler poultry litter and commercial fertilizer for coastal bermudagrass production in the southern US. Journal of Sustainable Agriculture, 12 (4): 55-77.

Ferguson, R.B., Nienaber, J.A., Eigenberg, R.A., and Woodbury, B.L. (2005) Longterm effects of sustained beef feedlot manure application on soil nutrients, corn silage yield, and nutrient uptake. Journal of Environmental Quality, 34: 1672-1681.

Franzluebbers, A.J., Wilkinson, S.R., and Stueddemann, J.A. (2004) Bermudagrass management in the southern piedmont USA, VIII: soil $\mathrm{pH}$ and nutrient cations. Agronomy Journal, 96: 1390-1399.

Gascho, G.J. and Hubbard, R.K. (2006) Long-term impact of broiler litter on chemical properties of a coastal plain soil. Journal of Soil and Water Conservation, 61: $65-74$.

He, Z., Griffin, T.S., and Honeycutt, C.W. (2004a) Enzymatic hydrolysis of organic phosphorus in swine manure and soil. Journal of Environmental Quality, 33: $367-372$.

He, Z., Griffin, T.S., and Honeycutt, C.W. (2004b) Evaluation of soil phosphorus transformations by sequential fractionation and phosphatase hydrolysis. Soil Science, 169: 515-527.

He, Z., Honeycutt, C.W., Senwo, Z.N., and Tazisong, I.A. (2005) Impacts of long-term poultry litter application on soil phosphorus. In Plant Nutrition for Food Security, Human Health and Environmental Protection; Li, C.J. et al. (ed.); Tsinghua University Press.: Beijing, China, 910-911.

He, Z., Senwo, Z.N., Mankolo, R.N., and Honeycutt, C.W. (2006) Phosphorus fractions in poultry litter characterized by sequential fractionation coupled with phosphatase hydrolysis. Journal of Food, Agriculture and Environment, 4: 304-312. 
Hue, N.V. (1992) Correcting soil acidity of a highly weathered Ultisol with chicken manure and sewage sludge. Communication Soil Science, and Plant Analysis, 23: $241-264$.

Jackson, W.A., Leonard, R.A., and Wilkinson, S.R. (1975) Land disposal of broiler litter-Changes in soil potassium, calcium, and magnesium. Journal of Environmental Quality, 4: 202-206.

Kingery, W.L., Wood, C.W., Delaney, D.P., Williams, J.C., and Miullins, G.L. (1994) Impact of long-term application of broiler litter on environmentally related soil properties. Journal of Environmental Quality, 23: 139-147.

Kingery, W.L., Wood, C.W., Delaney, D.P., Williams, J.C., Miullins, G.L., and Santen, E.van. (1993) Implication of long-term land application of poultry litter on tall fescue pastures. Journal of Production Agriculture, 6: 390-395.

McDowell, R.W. and Sharpley, A.N. (2004) Variation of phosphorus leached from Pennsylvanian soils amended with manures, composts or inorganic fertilizer. Agriculture, Ecosystems and Environment, 102: 17-27.

Mehlich, A. (1984) Mehlich 3 soil test extractant: a modification of the Mehlich 2 extractant. Communications in Soil Science and Plant Analysis, 15: 1409-1416.

Sharpley, A.N., Daniel, T., Sims, T., Lemunyon, J., Stevens, R., and Parry, R. (1999) Agricultural phosphorus and eutrophication (ARS-149); USDA Agricultural Research Service: Beltsville, Md..

Shortall, J.G. and Liebhardt, W.C. (1975) Yield and growth of corn as affected by poultry manure. Journal of Environmental Quality, 4: 186-191.

Sommers, L.E. and Nelson, D.W. (1972) Determination of total phosphorus in soils: a rapid perchloric acid digestion procedure. Soil Science Society of America Proceedings, 36: 902-904.

Tazisong, I.A., Senwo, Z.N., and Taylor, R.W. (2005) Trends in trace elements in an Ultisol impacted by long-term applied broiler litter. Bulletin of Environmental Contamination and Toxicology, 75: 975-981.

Toor, G.S., Hunger, S., Peak, J.D., Sims, J.T., and Sparks, D.L. (2006) Advances in the characterization of phosphorus in organic wastes: environmental and agronomic applications. Advances in Agronomy, 89: 1-72.

Weil, R.R., Kroontje, W., and Jones, G.D. (1979) Inorganic nitrogen and soluble salts in a Davidson clay loam used for poultry manure disposal. Journal of Environmental Quality, 8: 86-91.

Whalen, J.K. and Chang, C. (2001) Phosphorus accumulation in cultivated soils from long-term annual applications of cattle feedlot manure. Journal of Environmental Quality, 30: 229-237.

Williams, C.M., Barker, J.C., and Sims, J.T. (1999) Management and utilization of poultry wastes. Reviews of Environmental Contamination and Toxicology, 162: $105-157$.

Zhang, F., Ma, W., Zhang, W., and Fan, M. (2005) Nutrient management in China: from production systems to food chain. In Plant Nutrition for Food Security, Human Health and Environmental rotection; Li, C.J. et al. (ed.); Tsinghua University Press.: Beijing, China, 13-15. 